\title{
Maternal serum $\beta$ hCG level and uterine artery doppler studies as predictors of pregnancy induced hypertension and intra uterine growth restriction: a prospective study
}

\author{
Vishal S. Sheth*, Kanaklata D. Nakum, Mehul D. Patel, Mayank R. Lunagariya
}

Department of Obstetrics and Gynecology, Government Medical College, Bhavnagar, Gujarat, India

Received: 15 June 2019

Accepted: 12 July 2019

*Correspondence:

Dr. Vishal S. Sheth,

E-mail: vishu.sheth89@gmail.com

Copyright: () the author(s), publisher and licensee Medip Academy. This is an open-access article distributed under the terms of the Creative Commons Attribution Non-Commercial License, which permits unrestricted non-commercial use, distribution, and reproduction in any medium, provided the original work is properly cited.

\begin{abstract}
Background: PIH, a pregnancy-specific disorder, is one of the major causes of maternal and perinatal morbidity and mortality worldwide.PIH and fetal growth restriction are important causes of perinatal and maternal morbidity and mortility.

Methods: Hundred Indian pregnant women in their second trimester (13-20 weeks) and in their late second trimester (24-28 weeks) investigated for their serum $\beta$-hCG level and uterine artery Doppler studies respectively, attending OPD/IPD in Sir T. hospital, Bhavnagar from June 2014 to June 2015.

Results: There is no clinical significance between parity and occurrence of PIH $(p=0.2)$ and FGR ( $p=0.7)$. Out of 77 patients with their $\beta$ hCG level $\leq 2 \mathrm{MoM}, 2$ patients $(2.59 \%)$ developed PIH and FGR. And from 12 patients with their $\beta$ hCG level $\geq 2$ MoM 10 patients $(80 \%)$ developed PIH and FGR which is highly significant $(p<0.001)$. The study establishes the validity of beta HCG as a predictor of PIH and FGR with the sensitivity of $83.3 \%$, specificity of $97.5 \%$.

Conclusions: This study can be concluded by there is a strong association between high maternal serum B-hCG level, abnormal uterine Doppler studies with predicting adverse outcome of pregnancy like PIH and FGR. There is also a good association between high maternal serum B-hCG level and rising severity of the disease.
\end{abstract}

Keywords: PIH, Serum B-hcg, Uterine artery Doppler

\section{INTRODUCTION}

$\mathrm{PIH}$, a pregnancy-specific disorder, is one of the major causes of maternal and perinatal morbidity and mortality worldwide. PIH and fetal growth restriction are important causes of perinatal and maternal morbidity and mortility. ${ }^{1,2}$ Berg and Colleagues (1996) reported almost $18 \%$ of 1450 maternal deaths in United States from 1987 to 1990 were complications of pregnancy related hypertension. ${ }^{3}$ Hypertension in pregnancy is also responsible for $18 \%$ of fetal and infant mortality as well as $46 \%$ of infants born small for gestational age. ${ }^{4}$ Similarly, it was estimated that from $3-10 \%$ of infants are growth restricted. The pathophysiology of pre-eclampsia is not precisely known but a two-step model that is widely accepted has been described..$^{5}$ The first step in the model has been proposed to be abnormalities of either differentiation of morula to blastocyst or the differentiation of trophoblast to cytotrophoblast or syncytiotropho-blast, which may cause inappropriate invasion of trophoblasts into the spiral arteries. ${ }^{6}$ The second step in the model is characterized by a general 
systemic inflammatory response of which endothelial dysfunction is a prominent part. $^{7}$ In pre-eclampsia histological examination reveal focal cellular necrosis in the syncytiotrophoblast and increased mitotic activity with cellular proliferation in the cytotrophoblast. Placental vascular damage leading to decreased oxygen supply might result in increased hCG production by hyperplastic cytotrophoblastic cells. The aim of this present study was to find out the role of $\beta$-hCG in pathogenesis of pre-eclampsia and its association with severity of pre-eclampsia. ${ }^{8}$ The persistence of high resistance to flow after 24-26 weeks of gestation provides the rationale to investigate the placental circulation by Doppler and to predict development of pre-eclampsia and fetal growth restriction. According to Brosen et al, Robertson et al, and Khong et al, a lack of endovascular infiltration by trophoblast into the myometrial portion of the placental bed spiral arteries is a consistent finding in the presence of preeclampsia. ${ }^{9-11}$ Since unconverted vessels retain 'high resistance/low capacitance properties, the effect on maternal blood supply to the placenta may be dramatically low. These may manifest as impaired growth of the baby and preeclampsia.

\section{METHODS}

Hundred Indian pregnant women in their second trimester (13 - 20 weeks) and in their late second trimester (24 - 28 weeks) investigated for their serum $\beta$-hCG level and uterine artery Doppler studies respectively, attending OPD/IPD in Sir T. hospital, Bhavnagar from June 2014 to June 2015. Women with multiple pregnancy, congenital malformation, essential hypertension, diabetes mellitus, molar pregnancy and history of down syndrome were excluded from the study. Gestational age was calculated from the reliable menstrual history dates and early ultrasonographical measurement of fetal crownrump length. The serum $\beta$-hCG estimation was done by Chemi-Luminescence Immune Assay (CLIA) method. The multiple of median (MOM) was calculated from the median of the diagnostic test and $\beta$-hCG was considered raised if levels were more than $2 \mathrm{MOM}$. In late $2^{\text {nd }}$ trimester (24-28 weeks), 100 patients who all were previously investigated for maternal serum $\beta$-hCG level, were included for evaluation by application of uterine artery Doppler studies. Parameters studied are S/D ratio, $\mathrm{RI}$ and early diastolic notch in uterine artery it considered abnormal if S/D ratio $>3.0 \mathrm{RI}>0.56$ and presence of Diastolic notch. These all patients were followed up till delivery and details of pregnancy events, labour and delivery and neonatal outcome were noted. The abnormal pregnancy outcomes considered are PIH and FGR. PIH is defined as hypertension $\geq 140 / 90 \mathrm{mmHg}$ after 20 weeks of gestation with or without proteinurea in previously normotensive and normoproteinuric women measured on two occasions at least 6 houra apart. FGR is defined as $<10^{\text {th }}$ percentile birth rate for that gestational age.

\section{Statistical analysis}

Statistical analysis was performed using programs available in the SPSS statistical package (SPSS 15.0, Chicago, USA), Microsoft Word and Excel. Association between screening test and occurrence of disease was calculated by Chi-square test. Yate's correction was applied when there was any requirement (i.e. cell numerical value $<5$ ).

\section{RESULTS}

Total hundred patient included in Study but only 89 followed till term. Table 1 shows the distribution of the cases.48 patients $(54 \%)$ are primigravida and $41(46 \%)$ patient are multigravida in study group and from that 12 patients (13.5\%) developed PIH and FGR. There is no clinical significance between parity and occurrence of PIH $(p=0.2)$ and FGR. $(p=0.7)$ (Table 2 and Table 3$)$.

As shown in Table 4 and Table 5 ,Among 89 patients were studied 77 patients had there $\beta$ hCG level $\leq 2$ MoM and 12 patient had there $\beta$ hCG $\geq 2$ MOM. Out of 77 patients with their $\beta$ hCG level $\leq 2$ MoM, 2 patients $(2.59 \%)$ developed PIH and FGR. And from 12 patients with their $\beta$ hCG level $\geq 2$ MoM 10 patients (80\%) developed PIH and FGR which is highly significant ( $p<0.001)$. The study establishes the validity of beta HCG as a predictor of PIH and FGR with the sensitivity of $83.3 \%$, specificity of $97.5 \%$.

Table 1: Outcome of pregnancy after recruitment.

\begin{tabular}{|c|c|c|c|c|}
\hline $\begin{array}{l}\text { Total no. of } \\
\text { cases }\end{array}$ & $\begin{array}{l}\text { Spontaneous } \\
\text { abortion }\end{array}$ & Missed abortion & $\begin{array}{l}\text { Lost to } \\
\text { follow up }\end{array}$ & $\begin{array}{l}\text { No. of cases followed till } \\
\text { delivery }\end{array}$ \\
\hline 100 & 2 & 3 & 6 & 89 \\
\hline
\end{tabular}

Table 2: Distribution of cases according to parity and occurrence of PIH.

\begin{tabular}{|llll|}
\hline Parity & Women with PIH (\%) & Women without PIH (\%) & Total \\
\hline Primigravida & $9(10.11 \%)$ & $39(43.82 \%)$ & $48(53.93 \%)$ \\
\hline Multigravida & $3(3.37 \%)$ & $38(42.69 \%)$ & $41(46.06 \%)$ \\
\hline Total & $12(13.48 \%)$ & $77(86.51 \%)$ & $89(100 \%)$ \\
\hline
\end{tabular}

Chi-square $=1.59$, degree of freedom $1, \mathrm{p}$ value $=0.2$. 
Table 3: Distribution of cases according to parity and occurrence of IUGR.

\begin{tabular}{|llll|}
\hline Parity & Women with IUGR (\%) & Women without IUGR (\%) & Total \\
\hline Primigravida & $7(7.86 \%)$ & $41(46.06 \%)$ & $48(53.93 \%)$ \\
\hline Multigravida & $5(5.61 \%)$ & $36(40.44 \%)$ & $41(46.06 \%)$ \\
\hline Total & $12(13.48 \%)$ & $77(86.51 \%)$ & $89(100 \%)$ \\
\hline
\end{tabular}

Chi-square $=0.108$ with 1 degree of freedom, $\mathrm{p}=0.7$

Table 4: Distribution of cases according to hypertensive status and $\beta$-hCG level.

\begin{tabular}{|lllll|}
\hline \multirow{2}{*}{ Beta-HCG Level (MOM) } & PIH Patients & & Normotensive & Total \\
\cline { 2 - 5 } & Mild PIH & Severe PIH & $75(84.26 \%)$ & $77(86.51 \%)$ \\
\hline$>2$ & $2(2.24 \%)$ & $0(0 \%)$ & $2(2.24 \%)$ & $12(13.48 \%)$ \\
\hline
\end{tabular}

Chi-square $=51.2$ with 1 degree of freedom, $\mathrm{P}<0.001$

Table 5: Distribution of cases according to $\beta$-hCG level and IUGR.

\begin{tabular}{|llll|}
\hline Beta-HCG Level (MOM) & Women with IUGR (\%) & Women without IUGR (\%) & Total \\
\hline$\leq 2$ & 2 & 75 & 77 \\
\hline$>2$ & 10 & 2 & 12 \\
\hline Total & $\mathbf{1 2}$ & $\mathbf{7 7}$ & $\mathbf{8 9}$ \\
\hline
\end{tabular}

Table 6: Distribution of cases according to $\beta$-hCG level and severity of PIH.

\begin{tabular}{|llll|}
\hline Beta HCG level $(\mathrm{m} / \mathrm{u} / \mathrm{ml})$ & Mild PIH $(\%)$ & Severe PIH $(\%)$ & Total \\
\hline$\leq 85000$ & $5(41.66 \%)$ & $1(8.33 \%)$ & $6(50 \%)$ \\
\hline$>85000$ & $1(8.33 \%)$ & $5(41.66 \%)$ & $6(50 \%)$ \\
\hline Total & $\mathbf{6}(\mathbf{5 0 \%})$ & $\mathbf{6}(\mathbf{5 0 \%})$ & $\mathbf{1 2}(\mathbf{1 0 0 \% )}$ \\
\hline
\end{tabular}

Fisher's exact test two tailed $\mathrm{p}$ value 0.0801 .

Table 7: Uterine artery Doppler as a predictor of PIH.

\begin{tabular}{|lllllll|}
\hline Doppler test & Sensitivity & Specificity & $\begin{array}{l}\text { Positive } \\
\text { predictive value }\end{array}$ & $\begin{array}{l}\text { Negative } \\
\text { predictive value }\end{array}$ & $\begin{array}{l}\text { Chi-square (with } \\
\text { yates correction) }\end{array}$ & $\begin{array}{l}P \\
\text { Value }\end{array}$ \\
\hline S/d ratio & $66.7 \%$ & $85.7 \%$ & $42.1 \%$ & $94.3 \%$ & 13.9 & 0.001 \\
\hline RI & $66.7 \%$ & $88.3 \%$ & $47.1 \%$ & $94.4 \%$ & 16.9 & 0.001 \\
\hline Notch & $91.7 \%$ & $84.4 \%$ & $47.8 \%$ & $98.5 \%$ & 31.5 & 0.001 \\
\hline Combined & $91.7 \%$ & $76.6 \%$ & $37.9 \%$ & $98.3 \%$ & 19.4 & 0.001 \\
\hline
\end{tabular}

Table 8: Uterine artery Doppler as a predictor of IUGR.

\begin{tabular}{|lllllll|}
\hline Doppler test & Sensitivity & Specificity & $\begin{array}{l}\text { Positive } \\
\text { predictive value }\end{array}$ & $\begin{array}{l}\text { Negative } \\
\text { predictive value }\end{array}$ & $\begin{array}{l}\text { Chi-square (with } \\
\text { yates correction) }\end{array}$ & $\begin{array}{l}P \\
\text { Value }\end{array}$ \\
\hline S/d ratio & $75.0 \%$ & $87.0 \%$ & $47.4 \%$ & $95.7 \%$ & 20.22 & 0.001 \\
\hline RI & $66.7 \%$ & $88.3 \%$ & $47.1 \%$ & $94.4 \%$ & 16.9 & 0.001 \\
\hline Notch & $83.3 \%$ & $83.1 \%$ & $43.5 \%$ & $97 \%$ & 23.9 & 0.001 \\
\hline Combined & $83.3 \%$ & $75.3 \%$ & $34.5 \%$ & $96.7 \%$ & 13.7 & 0.001 \\
\hline
\end{tabular}

As seen from Table 6 rising titer of $\beta$ hCG directly associated with increasing severity of $\mathrm{PIH}$, lout of 6 patient having severe $\mathrm{PIH}$ in $<85,000 \mathrm{mIU} / \mathrm{ml}$ but 5 out of 6 patient develop severe $\mathrm{PIH}$ in $>85,000 \mathrm{mIU} / \mathrm{ml}$ group ( $\mathrm{p}$ value $=0.08$ ). Now in uterine artery Doppler studies as seen from Table 7 S/D Ratio and RI notch had sensitivity of $66.7 \%$ and positive predictive value $42.1 \%$ and $47.1 \%$ respectively, while NOTCH is a single best predictor of $\mathrm{PIH}$ with sensitivity is $91.70 \%$ and positive predictive value $47.08 \%$.Combined parameter also have sensitivity high $91.7 \%$ but positive predictive value is less ( $\mathrm{p}$ value $<0.001)$. And uterine artery Doppler as a predictor of FGR as shown in Table 8 S/D Ratio and RI notch had sensitivity of $75.0 \%$ and $66.7 \%$ and positive predictive 
value $42.1 \%$ and $47.1 \%$ respectively, again $\mathrm{NOTCH}$ is a single best predictor of FGR with sensitivity is $83.30 \%$ and positive predictive value $43.5 \%$.Combined parameter also have sensitivity high $83.3 \%$ but positive predictive value is less.

When both maternal serum B-hCG and uterine artery Doppler was abnormal. $100 \%$ of patients developed PIH and $83.33 \%$ developed IUGR. When both were normal only 2 person $(16.66 \%)$ developed FGR.

\section{DISCUSSION}

The study was detailed and tailored to find the association between high serum B-hCG and the blood flow in uterine artery using Doppler ultrasound with the prediction of

FGR and pregnancy induced hypertension, using different evaluating tools such as MOM (multiple of median) for maternal serum $\beta$-hCG levels and S/D ratio, resistance index and early diagnostic notch for uterine artery Doppler ultrasound.

In this study the prevalence of PIH and IUGR is $13.4 \%$.

Patients in their second trimester of pregnancy (13-20 weeks) with higher levels of beta $\mathrm{HCG}>2$ MOM, developed PIH later in their pregnancy with $\mathrm{P}$ value $<0.001$, which were statistically significant. Out of 12 patients who developed PIH, 10 had increased their BhCG level with sensitivity of $83.33 \%$, specificity of $97.40 \%$, (p value $<0.001$ ), this result comparable to $G$ Kaur and et al. ${ }^{12}$

Among 6 severe PIH, 5 were with $B$-hCG level > 85,000, which showed that increased level of $B-h C G$ raises the severity of the disease. Though due to small sample size it is statistically not proven ( $\mathrm{p}$ value $=0.08$ ).

Among 89 patients 29 had abnormal Uterine Artery Doppler studies. Out of 29 patients 19 had increased S/D ratio, 17 had Increased RI, and 23 had Diastolic Notch.

Out Of 29 patients, 12 developed PIH with sensitivity of $66.7 \%$ for S/D ratio and resistance index and $91.7 \%$ for diastolic notch, positive predictive value of $42.1 \%, 47.1 \%$ and $47.8 \%$ for S/D ratio, resistance index and diastolic notch respectively ( $p$ value $<0.001$ ). These indicate that the diastolic Notch is the best predictor of PIH with higher sensitivity and positive predictive value.

And for FGR and Doppler among 29 patients who had abnormal Doppler studies, 12 developed FGR, with sensitivity of $75.0 \%, 66.7 \%$, and $83.3 \%$ for S/D ratio, resistance index and diastolic notch respectively and positive predictive value of $47.4 \%, 47.1 \%$, and $43.5 \%$ for $\mathrm{S} / \mathrm{D}$ ratio, resistance index, and diastolic notch respectively. This shows that diastolic notch is also a good predictor for FGR.
Out of 2 patients who had severe oligohydroamnios with elevated B-hCG level and abnormal uterine artery Doppler, 1 patient developed abruption of placenta due to severe PIH. One patient was induced for labour because of impending eclampsia at 35 weeks with abnormal $\beta$ hCG levels and Doppler studies who delivered IUGR baby with birth weight of $1.4 \mathrm{~kg}$.

These results support the earlier findings of Jain V et al. In which they proposed that serum beta HCG estimation at mid trimester (13-20 weeks) is a good predictor of PIH and higher levels of beta HCG are associated with increased severity of PIH. With sensitivity of $90.91 \%$, positive predictive value of $83.3 \%$ and specificity value of $97.44 \% .^{12}$

Harrington et al, reported significant association between abnormal flow of uterine artery Doppler and subsequent development of PIH and FGR. ${ }^{13}$ This study implies that abnormal $\beta$-hCG and uterine artery Doppler abnormalities associated with poor maternal and fetal outcome.

Further multicentric and larger sample size, study may require for biostatistically significant result approving null hypothesis.

\section{CONCLUSION}

This study can be concluded by there is a strong association between high maternal serum B-hCG level, abnormal uterine Doppler studies with predicting adverse outcome of pregnancy like PIH and FGR. There is also a good association between high maternal serum $B-h C G$ level and rising severity of the disease.

Among all parameters of uterine Doppler studies, early diastolic notch is a good predictor of PIH and FGR than S/D ratio and RI with higher sensitivity and positive predictive value. Thus, the maternal serum B-hCG level and uterine artery Doppler studies are good predictors of PIH and FGR.

\section{Funding: No funding sources \\ Conflict of interest: None declared \\ Ethical approval: The study was approved by the Institutional Ethics Committee}

\section{REFERENCES}

1. Report on Confidential Enquires into Maternal Deaths in the United Kingdom1991-1993. London: HMSO; 1996:20-31.

2. Berg CJ, Aftrash HK, Koonin LM, Tucker M. Pregnancy related mortality in the United States, 1987-1990. Obstet Gynecol. 1996;188:161.

3. Berg CJ, Aftrash HK, Koonin LM, Tucker M. Pregnancy related mortality in the United States, 1987-1990, Obstet Gynecol. 1996;188:161. 
4. Roberts JM, Hubel CA. The two stage model of preeclampsia: variations on the theme. Placenta. 2009;30 Suppl A:S32-7.

5. Roberts JM, Hubel CA. The two stage model of preeclampsia: variations on the theme. Placenta. 2009;30 Suppl A:S32-7.

6. Huppertz B. Placental origins of preeclampsia: challenging the current hypothesis. Hyper. 2008;51(4):970-5.

7. Roberts JM, Taylor RN, Musci TJ, Rodgers GM, Hubel CA, McLaughlin MK. Preeclampsia: an endothelial cell disorder. Am J Obstet Gynecol. 1989;161(5):1200-4.

8. Chaudhury KM, Das M, Ghosh S, Bhattacharya D, Ghosh TK. Value of serum beta hcg in pathogenesis of preeclampsia. J Clin Gynaecol Obstet. 2012;1(45):71-5.

9. Brosens IA, Robertson WB, Dixon HG. The role of spiral arteries in the pathgenesis of preeeclampsia. Obstet Gynecol Annu. 1972;1:117-91.

10. Robertson WB, Brosens I, Dixon G, Uteropcental vascular pathology. Eur J Obstet Gynecol Reprot Biol. 1975;5:47-65.
11. Khong TY, De Wolf F, Robertson WB. Inadequate maternal vascular response to placentation in pregnancies complicated by preeclampsia and by small-for -gestational age infants. $\mathrm{Br} \mathrm{J}$ Obstet Gynecol. 1986;93:1049-59.

12. Jain V, Himani S, Kaur G. Prediction of PIH by maternal serum beta HCG levels in the second trimester (13-20 weeks) of pregnancy. J Obstet Gynaecol India. 2012;62(1):32-4.

13. Harrington KF. Doppler velocimetry studies of the uterine artery in the early prediction of pre-eclampsia and intra-uterine growth etardation. Eur $\mathrm{J}$ Obstet Gynecol Reprod Biol. 1991;42:S14.

Cite this article as: Sheth VS, Nakum KD, Patel MD, Lunagariya MR. Maternal serum $\beta$ hCG level and uterine artery Doppler studies as predictors of PIH and IUGR: a prospective study. Int J Reprod Contracept Obstet Gynecol 2019;8:3357-61. 